\title{
MEIOFAUNA AND MICROPHYTOBENTHOS OF MARTEL INLET (ADMIRALTY BAY, KING GEORGE ISLAND, ANTARCTICA)
}

http://dx.doi.org/10.4322/apa.2014.012

Thaís Navajas Corbisier ${ }^{1 *}$, Rodrigo Soares Pereira Skowronski 2; Paula Foltran Gheller ${ }^{1}$ \& Mônica Angélica Varella Petti

Instituto Oceanográfico, Universidade de São Paulo, São Paulo, SP, Brazil

2 PIR2 Consultoria Ambiental, Rio de Janeiro, RJ, Brazil

e-mail: tncorbis@usp.br

Studies on the meiofauna community in Admiralty Bay started in 1991, when samples were collected through SCUBA diving in front of the Brazilian Station "Comandante Ferraz" (Martel Inlet) at depths ranging from 6 to $25 \mathrm{~m}$. The dominant groups were Nematoda and Harpacticoida, followed by nauplii and Polychaeta. The density of meiofauna in Martel Inlet, excluding the ice scour affected areas, was high, and varied from $3,523 \pm 2,117$ to $7,641 \pm 388$ ind. $10 \mathrm{~cm}^{-2}$ (mean $\pm \mathrm{SD}$ ) at 6-11 m depth, and from $3,479 \pm 1,205$ to $8,216 \pm 3,030$ ind. $10 \mathrm{~cm}^{-2}$ at $18-25 \mathrm{~m}$ depth (Skowronski et al., 1998).

Further samplings, including measurement of microphytobenthic biomass, were done at $15-20 \mathrm{~m}$ depth in seven areas of Martel Inlet: in front the Brazilian Station (CF), Yellow Point (YP), Rock O'Connor (RO), Ullman Point (UP), Botany Point (BP), Hennequin Point (HP) and Plaza Point (PP) (Figure 1). The sampling was undertaken during two consecutive summers (1996/97 and 1997/98) and the results revealed that high meiofaunal densities are characteristic of this whole inlet, varying between $1,952 \pm 326$ and $6,738 \pm 1542$ ind. $10 \mathrm{~cm}^{-2}$ and were correlated with the percentage of gravel, silt and clay (Skowronski \& Corbisier, 2002). In both summers, the areas with the highest densities were CF and UP and also HP in the first summer and PP in the second (Figure 1). There was no significant difference in the densities between the two summers, although the higher value of microphytobenthic biomass, the potential food for the meiofauna, was recorded in the first summer.
Horizontal differences were found in the microphytobenthic biomass throughout the inlet and seemed to be more related to the sediment characteristics, but no clear pattern of microphytobenthic distribution could be distinguished. An inter-summer variation was observed: the first summer showed the highest microphytobenthic biomass apparently related to more hydrodynamic conditions, which causes the deposition of allochthonous material (Skowronski et al., 2009).

A positive correlation between the microphytobenthos biomass and the meiofaunal densities was observed during the second summer, when the microphytobenthos biomass was approximately $25 \%$ lower than in the first summer (Skowronski et al., 2009). This might have acted as a limiting factor to the meiofauna in some of the areas (Skowronski \& Corbisier 2002). It may be supposed that the stronger hydrodynamic conditions of the first summer led to a high deposition of phytodetritus (phaeopigments), which masked the interaction between the meiofauna and the microphytobenthos.

The bathymetric variation of the meiofauna and the microphytobenthos was also evaluated along transects (10 to $60 \mathrm{~m}$ depth) in five areas (CF, YP, RO, UP and BP) in Martel Inlet during the summer of 1997/98 and 2004/05 (Gheller, 2007; Skowronski et al., 1998; 2009). Concerning the microphytobenthos, mean biomass values were inversely related to the depth gradient. The highest values were found at 10 to $20 \mathrm{~m}$ (mean $\pm \mathrm{SD}$ : 136.2 $\pm 112.5 \mathrm{mg} \mathrm{Chl} a . \mathrm{m}^{-2}, 261.7 \pm 455.9 \mathrm{mg}$ Phaeo. $\mathrm{m}^{-2}$ ), 


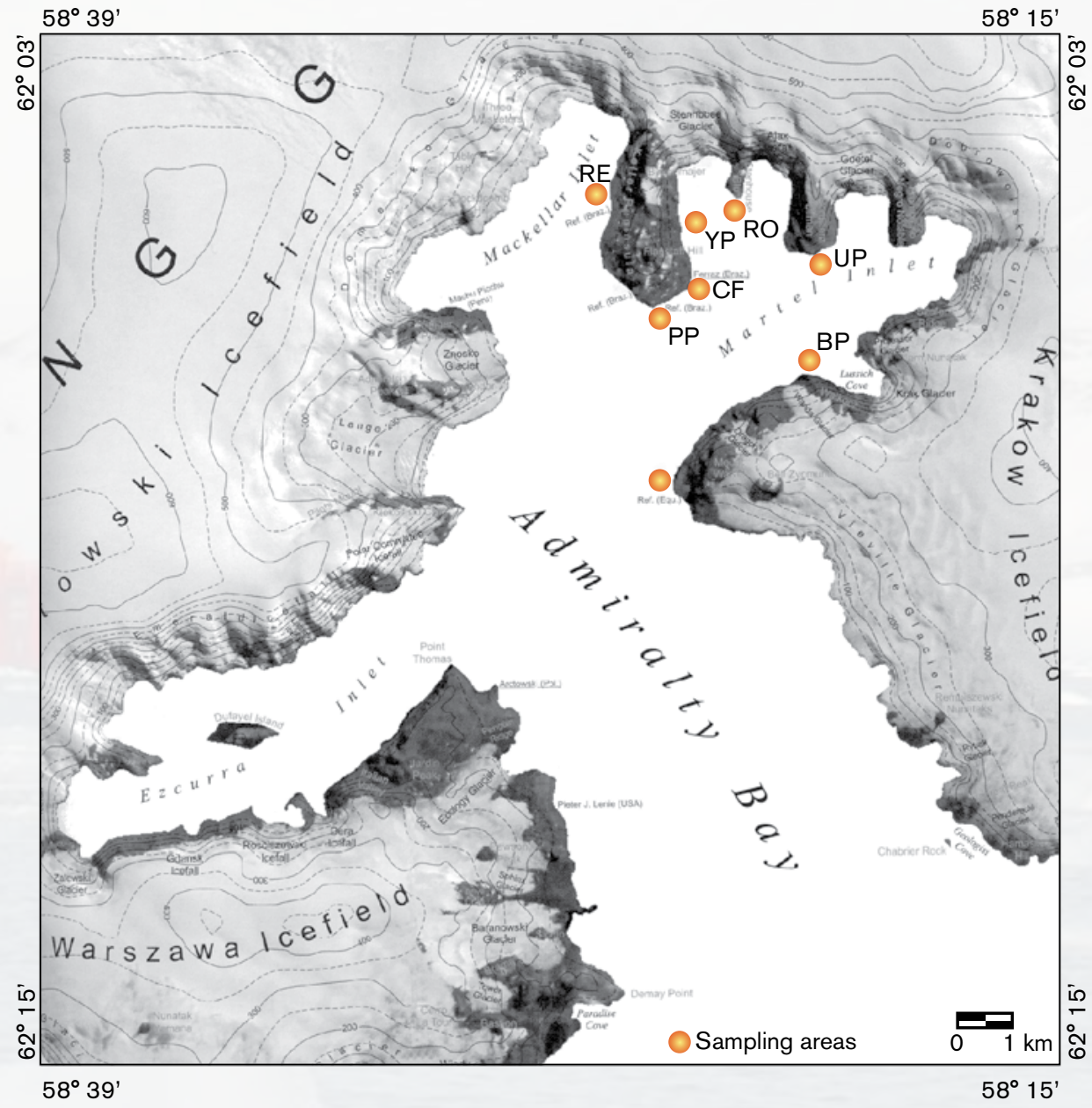

Figure 1. Admiralty Bay, King George Island. Sampling areas: PP - Plaza Point; CF - off Brazilian Antarctic Station "Comandante Ferraz"; YP - Yellow Point; RO - Rock O'Connor; UP - Ullmann Point; BP - Botany Point; HP - Hennequin Pointr; RE - Refuge 2. Adapted from Braun et al. (2001).

slightly lower at 20 to $30 \mathrm{~m}\left(55.6 \pm 39.5 \mathrm{mg} \mathrm{Chl}\right.$ a.m $\mathrm{m}^{-2}$, $108.8 \pm 73.0 \mathrm{mg}$ Phaeo. $\mathrm{m}^{-2}$ ), and the lowest ones were found at 40 to $60 \mathrm{~m}\left(22.7 \pm 23.7 \mathrm{mg} \mathrm{Chl} a \cdot \mathrm{m}^{-2}\right.$, $58.3 \pm 38.9 \mathrm{mg}$ Phaeo. $\mathrm{m}^{-2}$ ), comparable to those found in tropical regions at depths between 0 and $5 \mathrm{~m}$ (Cahoon, 1999). There was also a reduction in the $\mathrm{Chl} a / \mathrm{Phaeo}$ ratio in relation to depth, from $3.2 \pm 3.2$ at $10-20 \mathrm{~m}$ to $0.7 \pm 1.0$ at $40-60 \mathrm{~m}$, showing a higher contribution of senescent phytoplankton and/or macroalgae debris at the deeper sites and the limited light flux reaching the bottom.

The decrease of meiofauna densities in relation to increasing depth was observed. CF and RO had their highest densities at $25 \mathrm{~m}$, while YP and UP had theirs at $10 \mathrm{~m}$. It would seem that the influence of the ice scours at the first two sites disturbed the shallower zone at about $10 \mathrm{~m}$, because at UP and YP the local topography and circulation hindered the effect of excavation by ice blocks (Skowronski, 2002). Ice scours in shallow Antarctic zones have a negative effect on the meiofauna (Skowronski et al., 1998; Lee et al., 2001). Below $40 \mathrm{~m}$ the densities were much lower possibly because of the reduction in food supply, mainly the microphytobenthos (Skowronski, 2002; Gheller, 2007). The high benthic microalgal biomass on the two-first centimeters of sediments of the shallow coastal zone must be ecologically important to sustain the abundant benthic communities in Martel Inlet, since Admiralty Bay is considered an area where the pelagic primary production is low (Brandini \& Rebello, 
1994; Lange et al., 2007). The coupling of many abundant benthic macroinvertebrates and the meiofauna with the organic matter of the microphytobenthos was verified by carbon stable isotopic analysis (Corbisier et al., 2004).

Nematodes are the dominant meiofaunal group of Martel Inlet soft bottoms, representing more than $85 \%$ of this fauna, from 6 to $60 \mathrm{~m}$ depth. Until now 98 genera belonging to 28 families were identified (Skowronski et al., 1998; Skowronski, 2002; Gheller, 2007). This is a high diversity when compared to the values found in the few studies undertaken in the Antarctic coastal zone (between 19 and 49 genera and 11 to 19 families) (Vanhove et al., 1998; Lee et al., 2001). The most frequent genera were the non-selective depositivores Sabatieria, Odontophora, Axonolaimus, Paralinhomoeus and Daptonema and the epistrate feeders Microlaimus, Dichromadora, Prochromadorella and Acantholaimus. The predators/omnivores and selective depositivores genera were less numerous. The diversity of genera was related to the grain size and the availability of food, mainly microphytobenthos (Skowronski, 2002; Gheller, 2007).

A study on meiofaunal polychaetes in the nearshore zone in front of the Brazilian Station (Martel Inlet) showed that more than $70 \%$ were young individuals, mainly of three species: Apistobranchus glacierae, Leitoscoloplos kerguelensis and Ophryotrocha notialis. However, these are considered temporary meiofauna, and their distribution patterns were strongly related to the macrofaunal polychaetes in the same area (Bromberg et al., 2000; Petti et al., 2006).

Samples between 100 to $500 \mathrm{~m}$ depth were collected in Admiralty Bay in the summer of 2008/09 and 2009/10 during the International Polar Year (MABIREH Project), so additional information about the microphytobenthos and the meiofauna in deeper areas will be available soon.

Due to the meiofauna characteristics, such as small size, limited mobility, short life cycle lived entirely in the sediment, reproductive strategy without a larval dispersion phase, and intimate association with and dependence on the bottom environment (sediment and interstitial water), this community has been used for environmental monitoring (Coull \& Chandler, 1992; Schratzberger et al., 2000). In this sense, a meiofaunal study was undertaken in the summer of 2004/2005 and aimed to verify possible impacts due to the Brazilian activities, comparing CF with a reference area (BP) (Gheller, 2007). Results showed no significant differences in composition and abundance of meiofauna and nematodes between the two areas, which could indicate an anthropogenic impact near the Brazilian Station. A monitoring program (INCT-APA) was also established since this last summer (2009/10) when the meiofauna and the microphytobenthos were sampled at three sites in Martel Inlet (CF, UP and BP) and one in Mackellar Inlet (RE) (Figure 1).

\section{References}

BRANDINI, F. P.; REBELLO, J. Wind effect on hydrography and chlorophyll dynamics in the coastal pelagial of Admiralty Bay, King George Island, Antarctica. Antarctic Science, v. 6, p. 433-442, 1994.

BRAUN, M. et al. King George Island Satellite Map (1:100.000). 2001.

BROMBERG, S. et al. Polychaete distribution in the nearshore zone of Martel Inlet, Admiralty Bay (King George Island, Antarctica). Bulletin of Marine Science, v. 67, p. 175-188, 2000.

CAHOON, L. B. The role of benthic microalgae in neritic ecosystems. Oceanogr. Oceanography and Marine Biology: An Annual Review, v. 37, p. 47-86, 1999.

CORBISIER, T. N. et al. Trophic relationships in the nearshore zone of Martel Inlet (King George Island, Antarctica): $\delta^{13} \mathrm{C}$ stable isotope analysis. Oceanography and Marine Biology: An Annual Review, v. 27, p. 75-82, 2004.

COULL, B. C.; CHANDLER, G. T. Pollution and meiofauna: field, laboratory and mesocosm studies. Oceanogr. Oceanography and Marine Biology: An Annual Review, v. 30, p. 191-271, 1992. 
GHELLER, P. F. 2007. A meiofauna e os Nematoda da enseada Martel (Antártica) e seu uso em monitoramento ambiental. 103 f. Dissertação (Mestrado) - Instituto Oceanográfico, Universidade de São Paulo.

LANGE, P. K. et al. Microphytoplankton assemblages in shallow water Admiralty Bay (King George Island, Antarctica). Polar Biology, v. 30, p. 1483-1492, 2007.

LEE, H. J. et al. Recolonisation of meiofauna after catastrophic iceberg scouring in shallow Antarctic sediments. Polar Biology, v. 24, p. 918-925, 2001.

PETTI, M. A. V. et al. Bathymetric distribution of the meiofaunal polychaetes in the nearshore zone of martel Inlet, King George Island Antarctica. Antarctic Science, v. 18, p. 163-170, 2006.

SCHRATZBERGER, M. et al. The structure and taxonomic composition of sublittoral meiofauna assemblages as an indicator of the status of marine environments. Journal of the Marine Biological Association of the United Kingdom, v. 80, p. 969-980, 2000

SKOWRONSKI, R. S. P. Distribuição espacial e variação temporal da meiofauna, com ênfase para o grupo Nematoda, na enseada Martel (Antártica). 112 f. Tese (Doutorado) - Instituto Oceanográfico, Universidade de São Paulo.

SKOWRONSKI, R. S. P.; CORBISIER, T. N. Meiofauna distribution in Martel Inlet, King George Island (Antarctica): sediment features versus food availability. Polar Biology, v. 25, p. 126-134, 2002.

SKOWRONSKI, R. S. P.; CORBISIER, T. N.; ROBLES, F. R. Meiofauna along a coastal transect in Admiralty Bay, King George Island (Antarctica). Pesquisa Antártica Brasileira, v. 3, p. 117-131, 1998.

SKOWRONSKI, R. S. P. et al. Distribution of microphytobenthic biomass in Martel Inlet, King George Island (Antarctica). Polar Biology, v. 32, p. 839-851, 2009.

VANHOVE, S. et al. The metazoan meiofauna in its biogeochemical environment: the case of an antarctic coastal sediment. Journal of the Marine Biological Association of the United Kingdom, v. 78, p. 411-434, 1998. 